\title{
Genetic Diversity of Holstein Friesian, Jersey and Local Cows under Field Condition
}

\author{
P.S. Chakrabortty ${ }^{1 *}$, R.P. Singh ${ }^{2}$ and C.K. Biswas ${ }^{1}$ \\ ${ }^{1}$ Department of Animal Science, BCKV, Mohanpur, Nadia, India \\ ${ }^{2}$ Department of Animal Genetics \& Breeding, SHUATS, Allahabad, India \\ *Corresponding author
}

\section{A B S T R A C T}

\begin{tabular}{|l|}
\hline K e y w or d s \\
$\begin{array}{l}\text { Genetic diversity, } \\
\text { Holstein Friesian, Jersey } \\
\text { cows, Field condition }\end{array}$ \\
\hline Article Info \\
\hline $\begin{array}{l}\text { Accepted: } \\
\text { 20 September } 2018 \\
\text { Available Online: } \\
\text { 10 October } 2018\end{array}$ \\
\hline
\end{tabular}

Present study was based on three genetic groups viz., Jersey $\times$ Local $(\mathrm{G} 1)$, Holstein Friesian $\times$ Local $(\mathrm{G} 2)$ and Local (G3) cows, data collected from the field condition of Allahabad district, to determine the effect of service period, gestation period and calving interval. High estimates of heritability (above 60\%) in broad sense were recorded for tall the characters under study. High heritability was observed for all traits viz.; service period according to genetic group $(70.79 \%)$, calving interval according to genetic group $(81.95 \%)$. Genetic distance plays a vital role, as parental diversity in optimum magnitude is required to obtain superior genotypes in segregating population. The crossing programme should be initiated between the genotypes belonging to more divergent clusters. The greater the distance between to clusters, the wider the genetic diversity between their genotypes.

\section{Introduction}

India is a country with diversified agroclimatic conditions where agriculture is the main occupation of over three-fourth of the Indians.

Mostly farmers are engaged in agricultural operations for about 8 to 9 months of the year. To the marginal farmers and landless, it is advantageous to rear a cow, buffalo and/or other livestock as a source of additional income.

According to the 2003 census data the country has 485 million livestock population and 489 million poultry population, having the second highest number of buffalo 97 million, the third highest number of sheep 61 million, the second highest number of goats 124 million, the sixth highest number of camels 632 million, the highest number of chickens 457 million and the fourth highest number of duck 33 million in the world.

\section{Objective}

To determine the effect of Genetic Group on all reproductive traits of Jersey $\times$ Local, Holstein $\times$ Local and Local breeds of cows.

To determine the effect of Season of Calving on all reproductive traits of Jersey $\times$ Local, Holstein $\times$ Local and Local breeds of cows. 
To determine the effect of Lactation Order of dam on reproductive traits of Jersey $\times$ Local, Holstein $\times$ Local and Local breeds of cows.

\section{Materials and Methods}

Around the Uttar Pradesh, the reproductive record was collected by providing questionnaires.

The data thus obtained were classified according to genetic group as Jersey $\times$ Local (G1), Holstein Friesian $\times$ Local $(\mathrm{G} 2)$ and Local (G3) cows; according to season of calving as Summer monsoon: March to May (S1), Rainy Season: June to September (S2) and Winter: December to February (S3) and according to lactation order as $1^{\text {st }}(\mathrm{L} 1), 2^{\text {nd }}$ (L2), $3^{\text {rd }}(\mathrm{L} 3), 4^{\text {th }}(\mathrm{L} 4)$, and $5^{\text {th }}$ (L5) parity.

\section{Heritability (Broad sense)}

Heritability in broad sense is the ratio of genotypic variance to the total variance.

It was calculated by the formula given by Burton and Devane (1953).

$\mathrm{h}^{2}=(\mathrm{VG} / \mathrm{VP}) \times 100($ Where, $\mathrm{VG}=$ Genotypic variance. $\mathrm{VP}=$ Phenotypic variance.)

Johanson et al., (1955). Suggested heritability value as follows Low: Less than $30 \%$, Moderate: 30-60\%, High: More than 60\%

\section{Genetic advance}

The genetic variance i.e., expected genetic gain was worked out by using the formula suggested by Johanson et al., (1955). G.A. = $\mathrm{K} . \sigma_{\mathrm{p}} \cdot \mathrm{h}^{2}$ (Where, $\mathrm{K}=$ Selection differential coefficient in standard units, which is 2.06 for $5 \%$ selection intensity. $\sigma_{p}=$ Phenotypic standard deviation. $\mathrm{h}^{2}=$ Heritability in broad sense.) Genetic advance as per cent of mean was determined as: $(\mathrm{GA} /$ Grand mean $) \times 100$

\section{Genetic diversity and collection of data}

The calculation of $\mathrm{D}^{2}$ values involved following steps. Consider ' $v$ ' population and in each case ' $p$ ' characters have been measured on each individual. The data thus available can be represented in the form tables.

\section{Test of significance}

From the data variances and co-variances were calculated using Burton (1953) model. From these estimates a dispersion table was prepared using ' $\mathrm{V}$ ' statistics which in turn, utilizes Wilk's criteria, as simultaneous test of differences between mean values of a number of correlated variables is done (Rao, 1948).

\section{Transformation of correlated variable}

The original mean were subjected to get uncorrelated values $\left(\mathrm{X}_{\mathrm{s}}\right)$ were first transformed to uncorrelated ones $\left(\mathrm{Y}_{\mathrm{s}}\right)$, following the pivotal condensation method (Rao, 1952).

The $\mathrm{y}_{\mathrm{j}}$ were then transformed to $\mathrm{Y}_{\mathrm{js}}$ by division of the corresponding standard deviation with relation. $Y_{1}=y_{j} / y_{a r}\left(Y_{j}\right)^{0.5}$. So, as to make the variance of $y_{1}=1$

\section{Calculation of $\mathrm{D}^{2}$ statistics}

$\mathrm{D}^{2}$ between any two population or genotypes was calculated as the sum of squares of differences in the values between pairs of corresponding mean values of the transformed characters. i.e. $=\mathrm{S}\left(\mathrm{Y}_{\mathrm{i}}{ }^{1}-\mathrm{Y}_{\mathrm{j}}{ }^{2}\right)=\mathrm{D}^{2}$ (Where, $\mathrm{I}=$ $1,2, \ldots \mathrm{P})$.

\section{Testing the significance of $\mathrm{D}^{2}$ value}

The $\mathrm{D}^{2}$ value obtained for a pair of population is taken as the calculated value of ? ${ }^{2}$ and is tested value $?^{2}$ for ' $\mathrm{P}$ ' degrees of freedom, where $\mathrm{P}$ is number of characters considered. 
Contribution of individuals characters towards divergence

In the combinations each characters was ranked on the basis of $d_{1}=Y_{i}^{j} Y_{i}^{r}$ values. Rank 1 was given to highest mean difference and ranked $\mathrm{P}$ to the lowest mean difference, where $\mathrm{P}$ is the total number of characters considered.

\section{Group constellation}

The $\mathrm{D}^{2}$ values were arranged in an increasing order of magnitude. The grouping of the genotypes into cluster was done by using Tocher's method (Rao, 1952).

The two most closely associated genotypes were chosen and then third genotypes were found which had the smaller average $\mathrm{D}^{2}$ from the first three and so on. At certain stage, $\mathrm{D}^{2}$ value did not fit in the formed group and therefore, taken in other cluster.

\section{Average intra and inter cluster distances}

The intra cluster $\mathrm{D}^{2}$ was calculated by the formula $\mathrm{SD}_{\mathrm{i}}^{2} / \mathrm{n}$, where $\mathrm{SD}_{\mathrm{i}}^{2}$ is the sum of the distances between all possible combinations [ $\mathrm{n}$ $=\mathrm{I}(\mathrm{i}-1) / 2]$ of the genotypes (i) includes in a cluster. All passible $\mathrm{D}^{2}$ values between the genotypes of two clusters were added then divided by $\mathrm{n}_{1} \mathrm{Xn}_{2}$ for computing inters cluster distance. (Where, $\mathrm{n}_{1}$ and $\mathrm{n}_{2}=$ the number of genotypes in two clusters.) The square root of average $\mathrm{D}^{2}$ value was worked out to calculate the average intra and inter cluster $(\mathrm{D})=$ value

\section{Cluster mean and cluster diagram}

The cluster mean for a particular trait is the summation of mean values of the genotypes included in a cluster divided by number of genotypes in the cluster. With the help of $\mathrm{D}^{2}$ value between and within clusters, diagram showing the relationship between different populations were drawn.

\section{Results and Discussion}

\section{Estimation of genetic parameters}

One of the important considerations in any animal improvement is the detailed study of genetic variability. Variability is a measure by estimation of mean genotypic and phenotypic coefficient of variation, heritability, genetic advance and genetic gain. Environment plays an important role in the expression of phenotype and genotype facts, which are inferred from phenotypic observations. Hence, variability can be observed through biometric parameters like genotypic coefficient of variation, heritability (broad sense) and genetic advance which would be of great help to breeders in evolving a selection programme for genetic improvement of crop plants. The estimates of variance, coefficient of variation, heritability and genetic advance for all the characters under study have been explained as under.

\section{Estimates of phenotypic and genotypic variances}

\section{Service period}

The results are in confirmation to the findings of Deosarkar et al., (1989). These values alone are not helpful in determining the heritable portion of variation \{Falconar, (1960)\}. For this, estimates of heritability of these traits are necessary, which is reported in the following results. Higher magnitude of phenotypic coefficient of variation (PCV) was recorded for genetic group $(71.72 \%), \mathrm{G}_{2}$ cows $(22.14 \%)$ according to their season of calving, $\mathrm{G}_{3}$ cows (20.39\%) according to their lactation order. While moderate estimates were observed for $\mathrm{G}_{3}$ cows (19.26\%) according to their season of calving, $\mathrm{G}_{2}$ cows $(18.98 \%)$ according to their lactation order, $\mathrm{G}_{1}$ cows lactation order (17.79\%). Higher magnitude of genotypic coefficient of variation (GCV) was recorded 
for genetic group (70.79\%). While moderate estimates for $\mathrm{G}_{2}$ cows (10.45\%) according to their season of calving, $\mathrm{G}_{3}$ cows (10.02\%) according to their season of calving, and low estimates of genotypic coefficient of variation values was observed in lactation order (7.39\%) of $\mathrm{G}_{2}$ cows and lactation order $(5.17 \%)$ of $\mathrm{G}_{3}$ cows. Nayak et al., (2002) and Vivek et al., (2005) also reported high phenotypic coefficient of variation values. Jayasudha and Sharma (2010) also reported high GCV and PCV (Table 1 and Fig. 1).

\section{Gestation period}

Higher magnitude of phenotypic coefficient of variation $(\mathrm{PCV})$ was recorded for season of calving $(22.93 \%)$ of $\mathrm{G}_{2}$ cows, $\mathrm{G}_{3}$ cows (20.44\%) according to their season of calving. While moderate estimates were observed for $\mathrm{G}_{1}$ cows $(19.53 \%)$ according to their lactation order, $\mathrm{G}_{2}$ cows $(15.32 \%)$ according to their lactation order, $\mathrm{G}_{3}$ cows lactation order (12.3\%). Lowest magnitude of genotypic coefficient of variation (GCV) was recorded for lactation order (4.89\%) of $\mathrm{G}_{2}$ cows (Table 2 and Fig. 2).

\section{Calving interval}

Higher magnitude of phenotypic coefficient of variation (PCV) was recorded for genetic group $(23.10 \%)$, While moderate estimates were observed for $\mathrm{G}_{2}$ cows (10.59\%) according to their season of calving, $\mathrm{G}_{1}$ cows (10.52\%) according to their season of calving, $\mathrm{G}_{1}$ cows lactation order (17.79\%) (Table 3 and Fig. 3).

Higher magnitude of genotypic coefficient of variation $(\mathrm{GCV})$ was recorded for genetic group $(70.79 \%)$. While moderate estimates for $\mathrm{G}_{2}$ cows (10.45\%) according to their season of calving, $\mathrm{G}_{3}$ cows $(10.02 \%)$ according to their season of calving, and low estimates of genotypic coefficient of variation values was observed in lactation order $(7.39 \%)$ of $\mathrm{G}_{2}$ cows and lactation order $(5.17 \%)$ of $\mathrm{G}_{3}$ cows.

Table.1 Intra (diagonal) and inter cluster average distances for service period

\begin{tabular}{|c|c|c|c|c|c|c|c|c|c|}
\hline & GG & & & & & & & & \\
\hline GG & 1.000 & $\mathrm{~S}_{1}$ & & & & & & & \\
\hline$S_{1}$ & 0.259 & 1.000 & $\mathrm{~S}_{2}$ & & & & & & \\
\hline$S_{2}$ & -0.733 & -0.833 & 1.000 & $\mathrm{~S}_{3}$ & & & & & \\
\hline$S_{3}$ & -0.862 & 0.276 & 0.296 & 1.000 & $\mathrm{~L}_{1}$ & & & & \\
\hline $\mathrm{L}_{1}$ & 0.705 & 0.868 & -0.995 & -0.242 & 1.000 & $\mathrm{~L}_{2}$ & & & \\
\hline $\mathrm{L}_{2}$ & -0.325 & 0.834 & -0.390 & 0.764 & 0.445 & 1.000 & $\mathrm{~L}_{3}$ & & \\
\hline $\mathrm{L}_{3}$ & 0.149 & -0.926 & 0.553 & -0.637 & -0.607 & -0.987 & 1.000 & $\mathrm{~L}_{4}$ & \\
\hline $\mathrm{L}_{4}$ & 0.744 & -0.455 & -0.108 & -0.988 & 0.045 & -0.876 & 0.768 & 1.000 & $\mathrm{~L}_{5}$ \\
\hline $\mathrm{L}_{5}$ & 0.518 & -0.706 & 0.196 & -0.879 & -0.246 & -0.976 & 0.926 & 0.956 & 1.000 \\
\hline
\end{tabular}

Table.2 Intra (diagonal) and inter cluster average distances for gestation period

\begin{tabular}{|c|c|c|c|c|c|c|c|c|c|}
\hline & GG & & & & & & & & \\
\hline GG & 1.000 & $\mathrm{~S}_{1}$ & & & & & & & \\
\hline $\mathrm{S}_{1}$ & -0.961 & 1.000 & $\mathrm{~S}_{2}$ & & & & & & \\
\hline $\mathrm{S}_{2}$ & -0.484 & 0.214 & 1.000 & $\mathrm{~S}_{3}$ & & & & & \\
\hline$S_{3}$ & 0.826 & -0.625 & -0.891 & 1.000 & $\mathrm{~L}_{1}$ & & & & \\
\hline $\mathrm{L}_{1}$ & 0.263 & -0.523 & 0.717 & -0.335 & 1.000 & $\mathrm{~L}_{2}$ & & & \\
\hline $\mathrm{L}_{2}$ & -0.993 & 0.938 & 0.561 & -0.875 & -0.176 & 1.000 & $\mathrm{~L}_{3}$ & & \\
\hline $\mathrm{L}_{3}$ & -0.997 & 0.923 & 0.578 & -0.878 & -0.168 & 0.999 & 1.000 & $\mathrm{~L}_{4}$ & \\
\hline $\mathrm{L}_{4}$ & -0.883 & 0.720 & 0.836 & -0.999 & 0.201 & 0.924 & 0.930 & 1.000 & $\mathrm{~L}_{5}$ \\
\hline $\mathrm{L}_{5}$ & -0.352 & 0.601 & -0.649 & 0.238 & -0.993 & 0.260 & 0.253 & -0.116 & 1.000 \\
\hline
\end{tabular}


Table.3 Intra (diagonal) and inter cluster average distances for calving interval

\begin{tabular}{|c|c|c|c|c|c|c|c|c|c|}
\hline & GG & & & & & & & & \\
\hline GG & 1.000 & $\mathrm{~S}_{1}$ & & & & & & & \\
\hline$S_{1}$ & -0.445 & 1.000 & $S_{2}$ & & & & & & \\
\hline S2 & 0.517 & 0.533 & 1.000 & $\mathrm{~S}_{3}$ & & & & & \\
\hline$S_{3}$ & 0.795 & -0.900 & -0.111 & 1.000 & $\mathrm{~L}_{1}$ & & & & \\
\hline $\mathrm{L}_{1}$ & -0.043 & -0.879 & -0.876 & 0.575 & 1.000 & $\mathrm{~L}_{2}$ & & & \\
\hline $\mathrm{L}_{2}$ & 0.494 & 0.551 & 0.997 & -0.136 & -0.887 & 1.000 & $\mathrm{~L}_{3}$ & & \\
\hline $\mathrm{L}_{3}$ & -0.511 & 0.994 & 0.476 & -0.927 & -0.832 & 0.493 & 1.000 & $\mathrm{~L}_{4}$ & \\
\hline $\mathrm{L}_{4}$ & 0.984 & -0.583 & 0.373 & 0.889 & 0.123 & 0.343 & -0.644 & 1.000 & $\mathrm{~L}_{5}$ \\
\hline $\mathrm{L}_{5}$ & -0.990 & 0.401 & -0.556 & -0.769 & 0.087 & -0.538 & 0.470 & -0.975 & 1.000 \\
\hline
\end{tabular}

Fig.1 Cluster diagram (Service Period) depicting intra and inter cluster distances (The figure is not exactly to the scale) Enclidean ${ }^{2}$ Distance (Not to the Scale)

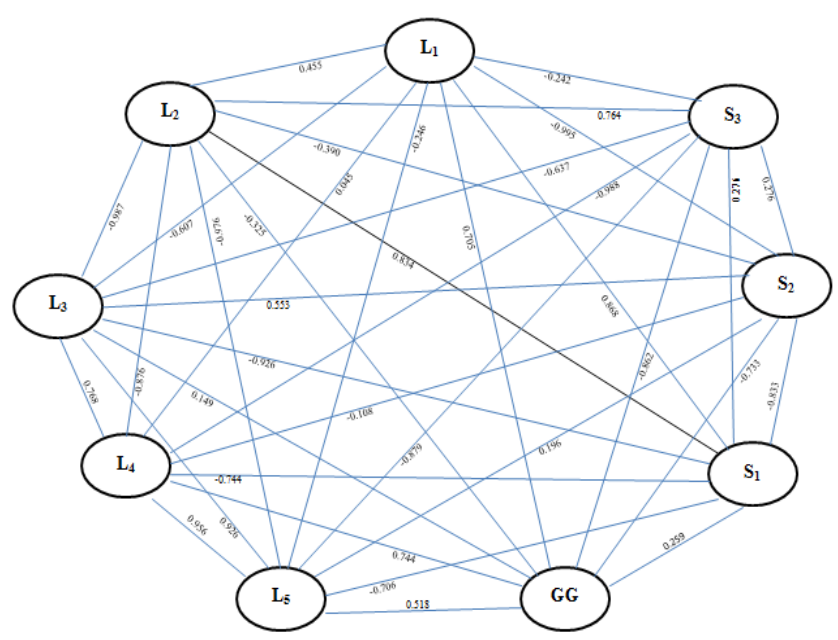

Fig.2 Cluster diagram (Gestation period) depicting intra and inter cluster distances (The figure is not exactly to the scale). Enclidean ${ }^{2}$ distance (Not to the scale)

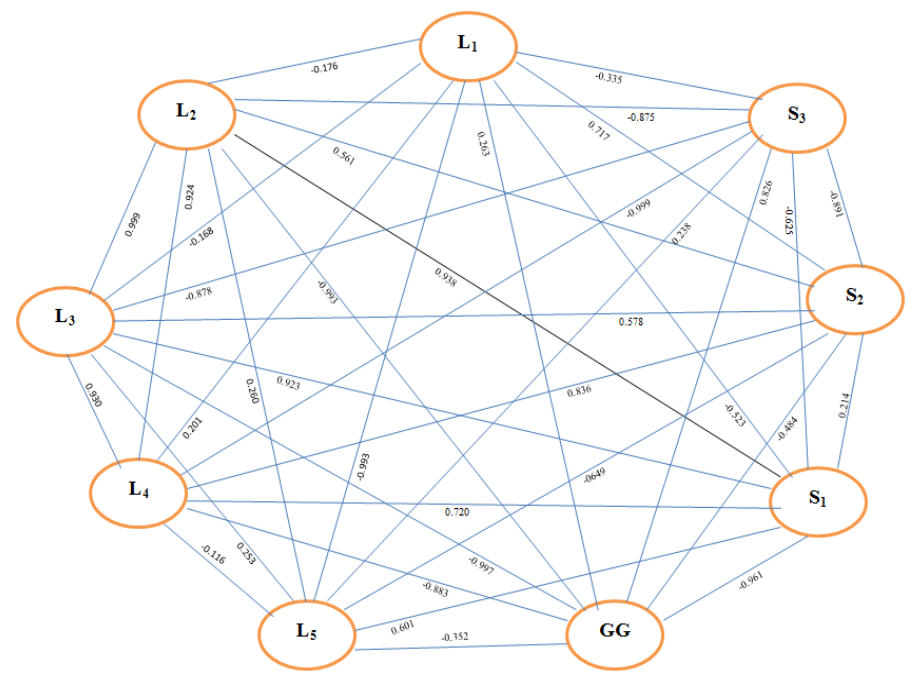


Fig.3 Cluster diagram (Calving interval) depicting intra and inter cluster distances (The figure is not exactly to the scale). Enclidean ${ }^{2}$ distance (Not to the Scale)

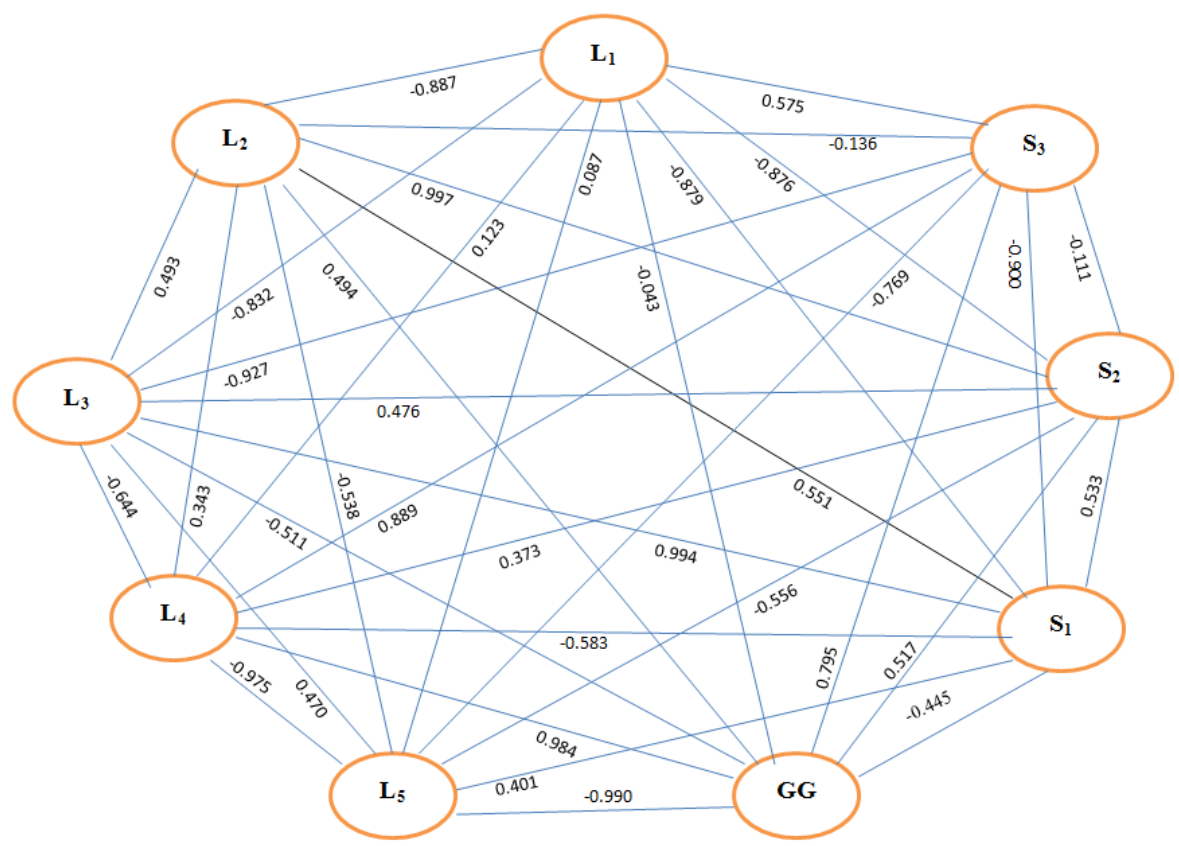

\section{Heritability and genetic advance}

Heritability is a measure of the extent of phenotypic variance caused by the action of genes. For making effective improvement in the character for which selection is practiced, heritability has been adopted by large number of workers as a reliable indicator. Heritability in broad sense according to Lush (1949), is the ratio total genotypic variance to phenotypic variance expressed in percentage. The estimates of heritability are more advantageous when expressed in terms of genetic advance. Johanson et al., (1955) suggested that without genetic advance the estimates of heritability will not be of practical value and emphasized the concurrent use of genetic advance along with heritability. Hanson (1963) stated that heritability and genetic advance have been worked out for all the quantitative characters. High estimates of heritability (above 60\%) in broad sense were recorded for all the characters under study. High heritability was observed for all traits viz.; service period according to genetic group
(70.79\%), calving interval according to genetic group (81.95\%). According to Panse (1957) such characters are governed predominantly by non-additive gene action and could be improved through individual plant selection. However, Nayak et al., (2002), Singh et al., (2006), Patil et al., (2003), Vivek et al., (2005) and Elayaraja et al., (2005) registered high estimates of heritability for grain yield per plant. Krishna et al., (2010) and Pandey and Anurag (2010) found high heritability coupled with high genetic advance.

\section{Genetic divergence}

Mahalanobis $\mathrm{D}^{2}$ statistics was used for the quantitative assessment of genetic divergence for all the characters. It is essential for increasing crop productivity through breeding. Selection of diverse parents in breeding programme helps in isolation of superior genotypes. Genetic diversity determines the inherent potential of across for heterosis and frequency of desirable 
recombinants in advanced generations. Genetic distance plays a vital role, as parental diversity in optimum magnitude is required to obtain superior genotypes in segregating population.

\section{Intra and inter cluster distance}

To realizer much variability and high heterotic effect, Pradhan and Roy, (1990); Mishra et al., (2003) and Chaturvedi and Maurya, (2005) recommended that parents should be selected from two clusters having wider inter cluster distance. Hybridization programme involving genetically diverse parents belonging to different clusters would provide an opportunity for bringing together gene constellations of diverse nature, promising hybrid derivatives resulted probably due to complimentary interaction of divergent genes in parents (Anand and Muthy, 1968). A crossing programme should be initiated between the genotypes belonging to more divergent clusters. The greater the distance between to clusters, the wider the genetic diversity between their genotypes. However, while considering genetic diversity among the parents to be included in hybridization programme, parents with high yielding potential and wide genetic diversity are likely to yield superior segregates within a short period (Roy and Panwar, 1993).

Based on per se performance for cows and other characters taken into consideration, this study concluded that Jersey $\times$ Local play important role in genetic group and at the same time Jersey $\times$ Local was reported to be an important trait in gestation period. The present investigation registered high heritability along with high genetic advance as percent of mean of service period, gestation period and calving interval which should be given top priority for effective selection. The present investigation further revealed that Jersey and Holstein Friesian are most diverse to each other. Therefore, genotypes present in these clusters are suggested to provide a broad spectrum of variability in segregating generations and may be used as parents for future hybridization programme to develop desirable type.

\section{References}

Anand, I.J. and Murthy, B.K. (1968). Genetic divergence and hybrid performance in linseed. Indian J. Genet., 28:178-185.

Burton G.W., Devane E.M. (1953). Estimating heritability from replicated clonal material. Agronomy Journal 1953; 45: 478-481.

Chaturvedi, H.P. and Mauraya, D.M. (2005). Genetic divergence analysis in Oryza sativa L. Advances P. Sci., 18(1): 349353.

Deoasarkar, D. B., Misal, M.B. and Nerkar, Y.S. (1989). Variability and correlation studies for yield contributing characters in breeding lines. J. Maharashtra. 14(1): 28-29.

Elayaraja, K., Prakash, M. and Kumar, B.S. (2005). Studies on variability and heritability of cattle. Crop Res., 5(213): 248-242.

Falconer, D.S. (1960a). Introduction to Quantitative Genetics. Oliver \& Boyd, Edinburg/ London.

Hanson, W.D. (1963). Heritability. Statistical genetics and plant breeding. NAS-NRC Publ. 982, 125-140.

Jayasudha, S and Deepak Sharma (2010). Genetic parameters of variability, correlation an path-coefficient. Electronic J. Pl. Breeding, 1:5, 13321338.

Johnson, G.H., Robinson, H.F., Comstock, R.E. (1955). Estimates of genetic and environmental variability in soybean. Agronomy Journal 1955; 47: 314.

Mishra, L.K., Sarawgi, A.K. and Mishra, R.K. (2003). Genetic diversity for 
morphological and quality traits. Adv. In plant Sci., 16(1): 287-293.

Nayak, A.R., Chaudhury, D. and Reddy, J.N (2002). Genetic variability, heritability and genetic advance in scented rice. Indian Agric., 46: 1/2, 45-47.

Pandey, Praveen and John Anurag, P. (2010). Estimation of genetic parameters in indigenous rice. Ad. In Agri. \& Bot. 2: 1-79.

Panse, V.G. (1957). Genetics of quantitative characters in relation of plant breeding. Indian J. Genet. 17: 318-324.

Patil, P.V., Sarawgi, A.K and Shrivastava, M.N. (2003). Genetic analysis of yield and quality traits in traditional aromatic accessions of rice. J. Maharashtra Agric. Uni., 28933): 255-258.
Rao, C.R. (1948). The utilization of multiple measurements in problems of biological classification. J. Joy Stat. Soc. 10(3): 159-203.

Rao, C.R. (1952). Advance statistical methods in biometrical research. John Wiley and Sons, Increased. New York.

Roy, A. and Panwar, D.V.S. (1993). Genetic divergence in rice genotypes. Ann. Agric. Res., 14(3): 276-281.

Singh, S.P., Singharia, G.S., Parray, G.A. and Bhat G.N. (2006b). Genetic diversity and character association studies in rice. Agri. Sci. Digest., 26(3): 212-214.

Vivek, S., Singh, S., Singh, S.K. and Singh, H. (2005). Estimation of genetic variability, heritability and genetic advance of different genotypes. Agric. Aci. Digest, 25(3): 207-209.

\section{How to cite this article:}

Chakrabortty, P.S., R.P. Singh and Biswas, C.K. 2018. Genetic Diversity of Holstein Friesian, Jersey and Local Cows under Field Condition. Int.J.Curr.Microbiol.App.Sci. 7(10): 2743-2750. doi: https://doi.org/10.20546/ijcmas.2018.710.319 